\title{
Liyofilizasyon: Genel Proses Değerlendirmesi
}

\author{
Mustafa Sencer Karagül ${ }^{1}$, Buket Altuntaş ${ }^{1}$ \\ Pendik Veteriner Kontrol Enstitüsü, Brusella Referans ve Aşı Üretim Laboratuvarl ${ }^{I}$
}

Geliş Tarihi / Received: 19.04.2018, Kabul Tarihi / Accepted: 17.05.2018

\begin{abstract}
Özet: Liyofilizasyon veya bir diğer adıyla dondurarak kurutma, final ürün özelliklerini, stabiliteyi ve verimi etkileyen kompleks bir proses olarak kabul edilmektedir. Liyofilizasyon, zorluklarına rağmen sunduğu avantajlar nedeniyle zoonoz hastalıkların da yer aldığı birçok hastalığa karşı uygulanan aşıların üretim zincirinde yer almaktadır. Aşılar diğer biyolojik maddeler veya mikroorganizmalar liyofilizasyon dışında, soğutma veya dondurma ile stabil hale getirilebilirler. Fakat ürünlerin donmuş fazda taşınması ve depolanmasının yüksek maliyeti yanında olası sistemsel arızalar ürünün yapısını bozarak kaybına neden olabilmektedir. Bu açıdan liyofilize formulasyonlar daha iyi stabilite avantajı ile birlikte, taşıma ve depolama sırasında da kolay idare sağlamaktadırlar. Bu derlemede, liyofilizasyon metodunun genel proses değerlendirilmesi yapılarak, prosesi oluşturan, dondurma, birincil kurutma ve ikincil kurutma basamakları arasındaki etkileşim açıklanmıştır. Canlı aşıların üretiminde önemli bir proses olan liyofilizasyon, prosesi uygulayan araştırmacıların gözünden değerlendirilmiş, üretim ve liyofilizasyon faaliyetlerinde bulunan çalışanlara yönlendirici ve destekleyici bilgiler paylaşılmıştır.
\end{abstract}

Anahtar kelimeler: Dondurma, Dondurarak-Kurutma, Liyofilizasyon, Stabilite,

\section{Liyophilization: A General Process Evaulation}

\begin{abstract}
Lyophilization, in other words, freeze drying is considered to be a complex process having an influence on the productivity, stability and the characteristics of the final product. Despite its difficulties, lyophilization is involved in the production chain of vaccines against some diseases, including zoonotic diseases, thanks to its advantages. Vaccines, other biological substances or microorganisms can be stabilized through cooling or freezing as well as lyophilization. However, transporting and storing the products in the frozen phase is rather expensive and some possible systematic problems might disrupt the product. For this reason, lyophilized formulations have the advantage of more stability; in addition, they are more manageable during transporting and storing. This review study evaluates the general process of lyophilization and reveals the interaction between the steps of freezing, primary drying and secondary drying, which constitute the process. Lyophilization, which is an important process for the production of live vaccines, has been evaluated from the perspective of the researchers who actually carry out the process and some guiding and helpful information for the ones that are involved in production and lyophilization activities has been included.
\end{abstract}

Key words: Freezing, Freeze drying, Lyophilization, Stability.

\section{Giriş}

Liyofilizasyon en basit haliyle, maddenin önce dondurulduğu ve sonrasında sublimasyon ve akabinde desorpsiyon ile solvent miktarının, biyolojik veya kimyasal reaksiyonları desteklemeyecek değerlere kadar azaltıldığ 1 bir stabilizasyon prosesi olarak tanımlanmaktadır $[7,10,13]$. Kriyopreservasyon (dondurarak saklama) ve dondurarak kurutma, maddelerin uzun dönem depolamasının sağlanmasinda tercih edilen teknikler olarak kabul edilmekte ve artan bir şekilde biyolojik materyallerin geniş bir aralığında uygulanmaktadır [15]. Dondurarak kurutma olarak bilinen liyofilizasyon; kuru, aktif, uzun raf ömrüne sahip ve kolayca çözülebilen bir ürün elde etmek için dondurma ve kurutma işlemlerinin faydalarını kombine eden bir proses olarak tanımlanmaktadır [1]. Hali hazırda pazarlanan biyofarmasötik ürünlerin \%50'sinin liyofilize formda olduğu aktarılmaktadır ki, bu haliyle en yaygın formulasyon stratejisini temsil etmektedir $[10,16,17]$. Uygulamanın temeli farklı metodolojiler için ortak olmasına rağmen, birçok laboratuvarın doğru preservasyon ve saklama prosedürlerinde uzmanlık bilgisi yetersiz kalmaktadır. Aynı zamanda buna bağl1 numune ve kültürlerin saklanmasinda uygun ve güncel olmayan protokoller uyguladığ 1 ifade edilmektedir [15]. Bu nedenle prosesi oluşturan basamakların değerlendirilerek iyi anlaşılması elzemdir. 


\section{Liyofilizasyon}

Liyofilizasyon, Yunanca 'çözücü seven-sıvı çeken' liyofil' teriminden türetilmiştir ve kuru bir ürünün yüksek seviyede tekrar rehidre olabilme yeteneğini ifade etmektedir $[10,13,26]$. Operasyonel olarak dondurarak kurutma, vakum desikasyonu aracil1ğıyla dayanıksız ürünlerin rehidre olmasının kontrol edilebilir bir metodu olarak açıklanabilir $[1,15]$. Liyofilizasyon, her bir basamağın kritik olduğu çok aşamalı bir operasyon olarak ifade edilmektedir. $\mathrm{Bu}$ proseste başarılı olabilmek için ana bileşenler iyi anlaşılmalı ve sıkı kontrol altında tutulmalıdır [26].

Biyolojik materyallerin stabil bir halde preservasyonu, biyolojik-medikal bilim, tarım ve biyoteknoloji için temel bir gereksinimdir [15]. Liyofilizasyon, farmasötik ve biyoteknoloji endüstrilerinde formulasyonların stabilitesini geliştirmek amacıyla yaygın olarak kullanılmaktadır [10,32]. Ayrıca, dayanıksız ilaçların özellikle terapötik proteinlerin uzun dönem stabilitelerini geliştiren önemli ve iyi bilinen bir prosestir [10,16,31]. Liyofilizasyon prosesi sonrasında kurumuş ve poröz yapıdaki ürün, karakteristik liyofil özelliği ile çözücüyü hızlıca absorbe ederek, proses öncesindeki orjinal yapısal formuna tekrar dönüşebilir [13]. Proses sonucu oluşan poröz yapıdaki ürün kekinin nem içeriği düşüktür ve belirlenmiş saklama koşullarında istenilen kullanımına kadar çok uzun süre depolanabilir [32].

Yaşam için vazgeçilmez olan su, hücre içindeki biyokimyasal aktiviteleri destekleyen yaygin bir solvent (çözücü) olarak metabolizmanın devamını ve bütün yaşamsal faaliyetleri destekler [15]. Dondururak kurutmaya tabi tutulan ürünler de, öncelikli olarak sudan yani solventten ve suyun içinde çözünen veya süspanse olan diğer materyallerden teşekküllerdir $[1,3,10,17]$. Su yokluğunda, canlı hücrelerde uyku hali veya ölüm fazının sonuçlanması ve hücresel ekstraktlarda biyokimyasal aktivitelerin inhibisyonu nedeniyle bildiğimiz yaşam devam edememektedir. Bu açıdan başarılı sonuçlar için sublimasyon ve desorpsiyon aşamalarında takip edilmesi gereken olay, liyofilizasyon prosesine maruz kalan ürüne ait bileşenlerden olan suyun uzaklaşmasıdır. Bu nedenle dayanıksız ürünleri stabilize etmek için depolanmış örneklerdeki su içeriğinin azaltılması veya immobilize edilmesi gereklidir. [1,15]
Liyofilizasyon prosesinde anahtar kelime, liyofilizasyon prosesinin bir stabilizasyon prosesi olarak kabul edilmesidir [13]. Stabilizasyon prosesi ise, bir maddenin doğal kinetik saatinin fazlasıyla değiştirilmesini içerir. Örneğin, bir aşının 2 gün +4 derecede depolanması neticesinde etkinliğinin \%90'a gerilediğini varsayalım. Eğer aşı içindeki nem miktarını düşürerek, kinetik saati yavaşlatılabilir ve 1 saniye zamanın etkisi 1 saate uzatılabilirse bu durumda aşının stabilitesi 2 gün yerine 20 yıla kadar çıkabilir [13]. Buradaki çarpıcı örnek, aslında liyofilizasyon prosesinin uygun şekilde yürütüldüğünde araştırmacılara ve üreticilere sunabileceği göz ardı edilemez fayda potansiyeline ışık tutmaktadır.

\section{Tarihçe}

Liyofilizasyon metodunun geçmişi, tarih öncesi zamanlara dayanmaktadır. Astek ve Eskimoların bu metodu gida maddelerinin saklanmasında kullandıkları paylaşılmıştır $[1,15]$. Aynı zamanda yine yüzyıllar önce aynı işlemin İnkalar tarafından And Dağları'nda Altiplano düzlüklerinin oksijeni az atmosfer ortamında ve güneşin radyan 1sısı altında et kurutmak için kullanıldığı aktarılmıştır [26].

1880'lerin sonlarına doğru, proses laboratuvar ölçeğinde kullanılmış ve temel prensipleri anlaşımıştır $[1,15] .1890$ yılında yaklaşık olarak $-20^{\circ} \mathrm{C}$ sicaklıkta ve subatmosferik basınç altında, dokuların kurutulabildiği bildirilmiştir. 1905 yılında ise araştırmacılar kimyasal bir pompa aracılı̆̆ıyla 1 ATM daha düşük bir basınç altında hayvan dokularının kurutulabildiğini paylaşmıştır [13]. Pratik olarak liyofilizasyon metodu, ssiya duyarlı antibiyotik ve kan ürünlerinin işlenmesine ihtiyaç duyulduğu 1930'lara kadar bir laboratuvar tekniği olarak kalmıştır [1,15].

\section{Kullanım alanları}

Liyofilizasyon termolabil (1sıya duyarlı) biyolojik materyallerin korunması için önemli bir prosestir. Günümüzde çeşitli endüstrilerde geniş kullanım alanına sahiptir [24]. Mikrobiyal kültür gibi can11 materyallerin stabilizasyonu, müzede sergilenen hayvan örneklerinin preservasyonu (taksidermi), çiçeklerin kurutulması (tahnitçilik) ve reaksiyon 
ürünlerin konsantrasyonu veya geri kazanımı gibi prosesler için farklı alanlarda kullanılmaktadır $[10,17]$. Liyofilizasyon, yangin veya sel sonucu hasara uğramış değerli el yazması kitap ve belgelerin kurtarılmasında da araç olmuştur. Bu tür uygulamalara sıklıkla ihtiyaç duyulmamakla birlikte, bu teknolojinin sonraki nesillere faydalı olabilecek uygulamalar olduğu gerçeği, aslında bu teknoloji tarafından sağlanan ödüllendirici bir mirastır [24].

Liyofilizasyon işleminin en yaygın kullanım alanlarından biri sağlık hizmetleri endüstrisidir. $\mathrm{Bu}$ alan, kimyasal bileşikler, parenteral formülasyonlar, aşılar ve ayrıca teşhis ürünlerindeki farmasötiklerin liyofilizasyonunu içerir. Liyofilizasyon, biyo-endüstri sektöründe, standart bir işleme tekniği haline gelerek üretilen yüksek kaliteli ve yüksek maliyetli ürünlerde (monokloanal antikor, antijen, DNA) stabilite sağlamaktadır [5]. Kültür koleksiyonlarında ve endüstri alanında kültür kurutma işlemi yaygın olarak kullanılmaktadır. Bunların dışında uzun süre depolanması için, sperm, eritrosit, plazma, ve serumun yanı sıra organ naklinde kullanılmak üzere bazı dokuların liyofilizasyon yöntemiyle saklanabildiği aktarılmıştır [11].

Liyofilizasyonun diğer bir yaygın kullanımı veteriner hekimlik ürünleridir. Bu ürünler bireysel evcil hayvanlar için yapılan aşılardan ruminant veya kanatlı aşıları gibi büyük ölçekli uygulamalara kadar çeşitlilik gösterir [28]. Gıdalar söz konusu olduğunda ise en yaygın olarak bilinen dondurarak kurutulmuş gıda ürünü kahvedir [13]. Ayrıca proses, astronot gidası olan dondurarak kurutulmuş dondurma formu ile de popülerleşmiştir [10]. Çay, meyve ve sebzeler, et ürünleri, hazır yiyecekler ve bazı aromatik otlar dondurularak kurutma işleminin uygulandığ 1 gida ürünleri olarak karşımıza çıkmaktadir $[5,6,24,25]$.

Çok çeşitli alanda liyofilizasyon işlemi başarılı bir şekilde uygulanabilir olmasına rağmen liyofilize edildikten sonra rekonstitüye edilen canlı organizmaların tekrar büyüme ve çoğalma kabiliyetini sürdürebilmeleri gerekmektedir. Bu nedenle hücre gibi bir canlı sistemin uzun vadeli korunması için başarılı bir uygulama sağlanması zaruriyeti bu alanda çalışan bilim insanları için en büyük zorluklardan biridir [7].

\section{Liyofilizasyon Basamakları}

\section{Dondurma}

Geleneksel bir liyofilizasyon siklusu 3 aşamadan oluşur: dondurma, birincil kurutma ve ikincil kurutma $[22,23]$. Bir formulasyonun başarılı şekilde liyofilize edilebilmesi için birincil kurutmaya başlamadan öncesi dondurulması gerekliliği söz konusudur [13]. Zira dondurarak kurutma, katı fazdan gaz faza doğru bir hal değişimi olduğu için, liyofilize edilecek olan materyalin önce dondurulması gerekir [10]. Dondurma, kavram olarak basit gibi görünse de, liyofilizasyon prosesinde büyük olasılikla en kompleks ve ayrıca en önemli basamaktır $[13,16]$. Bununla birlikte ürün kalitesi ve prosesi optimize etmek adına dondurma basamağının kontrolü son derece önemlidir [16]. Zira dondurma aşamasında şekillen mikroyapılar final ürün kalitesini, birincil ve ikincil kurutma hızını ve oranını belirlemektedir [7].

Kurutma işlemi sıklıkla günlere ihtiyaç duyarken, dondurma işlemi genellikle birkaç saat içinde sonlanır [8,31]. Dondurma prosesinin temel prensibi, solut (çözünen) kısımdan solventin (çözücü) ayrılmasıdır. Aköz sistemler için, bu durum suyun buz kristalleri oluşturması ve çözünen maddenin söz konusu buz kristalleri arasındaki intersitisyel bölgede sınırlandırılması şeklindedir [13]. Dondurma aşaması boyunca, likit formulasyon, buz gelişiminin takip ettiği buz nükleasyonu başlayana kadar soğutulur. Bu durum, suyun büyük kısmının, camsı ve/veya kristalin yapıdaki çözünen matriksinden buz kristalleri içinde seperasyonu ile sonuçlanır [8]. Ayrıca, buz nükleasyon kinetiği ve buz kristali gelişimi, donmuş ürün kekinin morfolojisini ve fiziksel şartını, akabinde sonuç olarak kurumuş ürünün nihai özelliklerini belirlemektedir. Buz morfolojisi de, birinci ve ikinci kurutmadaki sublimasyonu oranı ile direkt olarak ilişkilidir [9].

Dondurmadaki amaç, formulasyonun sıcaklığ1nı düşürerek, solut ve solventin ayrıldığı bir matriks elde etmektir. Bu sayede, matriksin intersitisyel bölgesindeki su mobilitesini sinırlandırmak ve sıfıra yaklaştırmak amaçlanarak kurutma prosesi boyunca su buhar akıșına minimal direnç gösterecek bir matriks yapısının elde edilmesi hedeflenmektedir [13]. Ayrıca solventin çözünen kısımdan ayrılması ile 
üründe termal degradasyon minimize edilebilmekte ve vakum uygulandiğında ürünün köpürmesi engellenebilmektedir [7,31].

Dondurma aşamasının kendisi aslında liyofilizasyondaki temel dehidrasyon basamağını oluşturur [16]. Solvent vazifesindeki su, likit formulasyondan, saf katı buz formunda uzaklaşır. Bu uzaklaşma, solut maddenin konsantrasyonunda çarpıcı değişikliklere öncülük eder [3,9]. Söz konusu buz kristallerinin oluşumu ile solut bileşenlerinin konsantrasyo$\mathrm{nu}$, gelişen buz kristalleri arasında artar ki bu durum kriyo-konsantrasyon olarak bahsedilir [8,16]. Söz konusu konsantre materyalleri içeren alanlar, suya göre daha düşük donma noktasına sahiptirler. Zira bir ürün, buz varlığı nedeniyle donmuş gibi gözükmesine rağmen, suspansiyondaki tüm solut donmadan aslında tamamen donmuş değildir $[3,10]$.

Ürünün elektriksel direnci, sıv1 fazdan kat1 faza geçtiğinden dramatik seviyede hemen hemen her zaman yükselir. Bunun nedeni iyon ve elektron mobilitesinin azalmasıdır. Bu durum, aynı noktada elektriksel direnç ve ürün sıcaklığı ölçülürse donma noktasının tespit edilebileceğini göstermektedir. Çünkü genellikle dirençte ani bir yükseliş söz konusu olur ki direnç ve sıcaklık eğrilerinin kesişme noktası yüksek doğrulukla donma noktası olarak kabul edilebilir [17].

Solusyonun donma denge noktasının altında sıv1 fazda tutulması derin soğutma (supercooling) olarak belirtilir. Genel olarak dondurma, derin soğutulmuş sudan buz kristalizasyonunu tanımlamaktadır [16]. Derin soğutma her zaman donma esnasında ve sıklıkla donma sıcaklığının 10-15 Co altında veya daha fazla bir aralıkta meydana gelir. [30]. Ciddi nükleasyon hacmine ulaşıldığında, buz kristalizasyonu bütün sistemde birden gerçekleşir $[2,16]$. Kristalizasyon başladığında, ürün sıcaklığı hızlıca denge donma noktasına yükselir [16,30]. Söz konusu Nükleasyon homojen ve heterojen olarak şekillenebilir $[9,13,16]$.Tüm farmasötik solusyonlarda ve steril filtre edilmiş enjenksiyonluk suda, nükleasyon heterojen nükleasyon olarak gözlemlenir $[9,16]$.

Özetle, soğutma ile sıcaklığı donma noktasına düşürülen formulasyon, derin soğutma ile daha düşük sıcaklıklarda katı forma geçmeden soğutulmaya devam edilir, başlayan buz nükleasyonunu, buz kristallerinin gelişimi ve ürünün tamamına yayılma-
S1 takip eder. Kristallerin gelişimi ile donma noktasının 10-15 derece altındaki formulasyon isınarak tekrar donma noktasına yaklaşabilir.

Oluşan buz çekirdekcik sayısı, buz gelişiminin oranı ve buz kristallerinin büyüklüğü derin soğutma derecesine bağlıdır $[13,21,29]$. Daha yüksek derin soğutma derecesi, daha yüksek nükleasyon oranı ve daha hızlı dondurma etki oranını oluşturmaktadır. $\mathrm{Bu}$ durum çok sayıda küçük buz kristal oluşumu ile sonuçlanmaktadır. Buna karşın, daha düşük derin soğutma derecesi, daha az sayıda fakat büyük buz kristal oluşumuna neden olmaktadır [3,16,29]. Derin soğutmayı düşürerek oluşturulan büyük buz kristalleri ile yüzey alanını minimize etmek istenilen bir diğer strateji olarak belirtilmiştir. [14,31].

Biyolojik standartların kurutulmasında, dondurma prosesi ayrıca önemlidir. Önceden soğutulmuş raflara ürünlerin konulması ile yapılan snap-ani dondurma, heterojenik kristal formasyonu ve final ürün görünümü ile sonuçlanabilmektedir [18,31]. Bununla birlikte eğer biyolojik bir üründe dondurma nedenli bir hasara meyil var ise bu durumda -50 derecede önceden soğutulmuş raflara ürünlerin yüklenmesi şeklinde olan hızlı dondurmaya alternatif yoktur. Tarihsel olarak sıvı nitrojen içinde ani dondurma mevcut üretim hacimlerinde ne güvenli ne de pratiktir ki sıklıkla yüksek oranda ampullerin kırılması ve kristalizasyon problemleri ile sonuçlanmaktadır. Adjuvant süspansiyonlar veya hücresel komponent içeren materyaller de ayrıca donmuş fazı tamamlamak için geçen zamanı ve sedimentasyon olasılığını minimize etmek için önceden soğutulmuş raflara yüklenirler. Hücresel ve viral yapıların hızlı dondurulması, daha küçük kristal oluşumu ile muhtemel kayıların asgariye indirebilmektedir [18].

Küçük buz kristal oluşumu, özelikle canlı aş1ların kurutulmasında tercih edilebilir bir yol olarak düşünülebilir. Hızlı soğutma ile küçük buz kristalleri elde edilebilir fakat büyük buz kristallerin şekillendiği yavaş kurutmaya kıyasla daha uzun kurutma süresi ihtiyacı doğar [3,7,29]. Çünkü hızl1 soğutmanın aksine yavaş soğutma ile kurutma prosesi boyunca ürün matriksi içinde buhar çık1şını daha az kısıtlayan kanallar oluşur. [10]. Lakin büyük buz kristallerin, aşı ürünü içeriğindeki canlı organizmalara vereceği zarar, liyofilizasyon kaybını yükselterek ürün kalitesini ve stabilitesini olumsuz 
yönde etkileyebilecektir. Bu nedenle hızlı soğutma ile mikroskobik yapıların korunması açısından sağlanan fayda unutulmamalıdır $[17,10]$. Ayrica dondurma, dolum hacmi ile de ilişkilidir. Zira, daha büyük dolum hacmini barındıran viallerin donması için daha uzun süre gerekir [29,31].

Biyolojik canlı ürünlerin liyofilizasyonunda, buz kristallerinin küçük olduğu, ani dondurma olarak anılan hızlı dondurma yönteminin tercih edilmesi prosesin daha başarılı sonuçlanmasına destek verebilecektir. Genel olarak $0.5 \mathrm{C} / \mathrm{dk}$ bir sicaklık düşüşü yavaş dondurmay1, $1 \mathrm{C}^{\mathrm{o}} / \mathrm{dk}^{\prime}$ l1k oran ise orta hizda dondurmayı tanımlamaktadır [7,31]. Dondurma prosesinin, reçeteye dökülmesinde ürüne ait kritik sıcaklıkları temsil eden Teu (ötektik sıcaklık), Tc (kollaps sıcaklığı) ve Tg (cam geçiş sıcaklığı)'nin göz önünde bulundurulması çok önemlidir [7,31]. Dondurma aşaması, uygun soğutma hızı, uygun derin soğutma sicaklığ1 ve yeterli donma süresi gibi anahtar parametreler takip edilirse başarılı sonuçlar sağlayabilir.

\section{Birincil Kurutma}

Birincil kurutma basamağ samak arasında en uzun süren basamaktır $[10,22]$. Bu basamakta, cihaz haznesi içindeki basınç düşürülür ve dondurma basamağında oluşan buz kristallerinin sublimasyonunu başlatmak adına ısı uygulanır [7,22]. Cihaz haznesi içindeki basınç vakum pompası arac1lığıyla düşürülür $[17,10]$. Vakum uygulaması, donmuş kütleden su buharının serbest göçüne izin verir. Sublimasyon devam ederken, donmuş kütle, kek tipi bir yapıya dönüşür [7]. Söz konusu sublimasyon, donmuş sıvının, sıvı faza dönüşmeden direkt olarak gaz aşamasına geçişi olarak açıklanabilir $[3,10,17]$. Birincil kurutma sonrası ikincil kurutmada sıcaklığın yükseltilmesiyle, eğer donmuş kısım üründen uzaklaştırılmamıșsa bu durum erime ile sonuçlanabilir. $\mathrm{Bu}$ yüzden birincil kurutmanın sona ereceği noktanın belirlenmesi çok önemlidir [10,17].

Birincil kurutmanın temel ideolojilerinden biri, ilk olarak optimum ürün hedef sıcaklığı belirlemek (Tp), akabinde ürünü hızlıca Tp değerine getirmek ve nihayetinde bu sıcaklık değerinde ürünü birincil kurutma boyunca bekletmektir [7,31]. Bu nedenle birincil kurutma boyunca sıcaklığın kritik proses s1caklık değerlerinin altında olmak kaydıyla olabildi- ğince yüksek tutulması gereği tavsiye edilmektedir. Söz konusu kritik proses sıcaklıkları amorf ürünler için Tc veya Tg ve kristalin yapılar için Teu erime noktasıdır [10,17]. Birincil kurutma boyunca ürün sicaklıkları genel olarak -35 ile -20 $\mathrm{C}^{\mathrm{o}}$ arasinda bulunabilmektedir. Ürün matriksi içindeki bağlı su, birincil kurutmadaki basınç değerleri kullanılarak fakat sıcaklık daha da fazla yükseltilerek uzaklaştirilir [19].

Tüm formulasyonların, proses defektlerini önlemek adına, komple bir solidifikasyon için daha düşük sıcaklıkta soğutulduğu ve birincil kurutma boyunca aynı düşük sıcaklığın sürdürüldügü bir kritik sıcaklığı bulunmaktadır. Tc sıcaklığı, materyalin yumuşayarak yapısını destekleyemediği noktadaki sıcaklık değeridir. Teu, solüt materyalin eridiği ve solvent uzaklaştıktan sonra herhangi bir yapının oluşmasının engellendiği sıcaklık değeridir. Tg ise donmuş materyalin kırılgan yapıdan esnek bir yapıya dönüştüğü sıcaklık değeridir [27].

Kabul edilir görünümde kurumuş ürün elde etmek için ürün sicaklığg her zaman, Tc' den birkaç derece düşük olmalıdır. Ürün sıcaklığı ile kollaps sicaklığı arasındaki fark, sicaklığın güvenlik marjini olarak tanımlanır. Daha yüksek ürün sıcaklığ daha hızlı bir proses sağlayabilir zira ürün sıcaklığındaki her $1 \mathrm{C}^{\mathrm{o}}$ artış birincil kurutma süresinde yaklaşık \%13' lük süre düşüşü sağladığı belirtilmiştir $[10,12,31]$. Bu açıdan çok düşük ürün sıcaklıkları ve bununla ilișkili düşük buz buharı basınç değerleri çok uzun süren birincil kurutmalar ile sonuçlanır [10]. Ürün sıcaklığı Tc değerine çok yakın olursa kollaps riski de yüksek olur [7,31]. Zira ürün sıcaklığındaki, kritik formulasyon sıcaklığının üzerinde bir artış çoğunlukla ürün kek yapısının kaybı ile sonuçlanır [10]. Bu açıdan, kristalize edice ajanların veya yüksek Tg değerine sahip desktran veya siklodekstrin gibi amorf yapıda katkıların ilavesi ile söz konusu kritik sıcaklıkların yükseltilmesi mümkün olabilir [4,10,17,].

Birincil kurutma boyunca kontrol edilebilir sadece iki tane proses parametresi bulunmaktadır: çember basıncı ve raf sıcaklığ $13,7,22,25]$. Çember basıncı, ürün sıcaklığındaki buzun buhar basıncından aşağıda olmalıdır. Bu sayede sublimasyon ile buz, üründen kondensere transfer olur ve kondenser plakalarında kristalize olabilir [7,10]. Liyofilizasyon haznesinde çok yüksek basınç olması, subli- 
masyon ara yüzeyi ile hazne arasındaki basınç gradiyentini düşürerek ve buna bağlı sublimasyonun devamı sağlayan itici gücü azaltarak sublimasyon oranını azaltabilir. Eğer hazne basıncı, sublimasyon ara yüzeyindeki buzun buhar basıncını geçerse, kütle transferi gerçekleşemez [10,17,]. En düşük çember basıncı değeri en hızlı buz sublimasyonunu sağlayabilir fakat çok düşük çember basıncı değerleri ürünün, tıpanın uçucu komponentleri ve vakum pompas1 yağı ile kontaminasyonuna neden olabilir. Ayrica, bu durum, vialler arasinda 1si transferi bakımından daha büyük heterojeniteler oluşturabilir. Pratikteki çoğu uygulamada, çember basınc1 50-200 mTorr arasında değişmektedir [31].

Birincil kurutma basamağ 1 için diğer önemli proses parametresi raf sıcaklığıdır. Kurutma boyunca hedef ürün sicaklığını koruyacak uygun raf sıcaklığını seçimi çok önemlidir. Birincil kurutma boyunca raf sıcaklığ 1 sublimasyona izin verecek optimumda olmalıdır. Eğer çok düşük olursa, Tp değerindeki buzun buhar basıncı ile çember basıncı arasındaki minimum fark dolayısıyla yeterli sublimasyonu oluşmayacaktır. Fakat çok yüksek olursa da kondenser sublime su buharını idare edemeyecektir [7,31]. Üründen suyun sublimasyonu için bir enerji gerekmektedir ki bu durum üründe soğumaya öncülük eder. Sublimasyonun devamı için ihtiyaç duyulan enerjinin, rafların belirlenmiş yüksek bir sıcaklığa 1sıtılmasıyla sağlanması gerekmektedir $[10,17]$.

\section{İkincil Kurutma}

Çok bileşenli aköz bir çözelti, buz sublimasyon s1nırına kadar dondurularak kurutulduğunda, donmamış rezidüel suyun geride kalan katı çözeltiden difuzyon, dezorpsiyon ve evoparosyon ile uzaklaştırdığ 1 proses ikinci kurutma olarak tanımlanmaktadır [9]. İkincil kurutma, solut fazdan donmamış suyun büyük kısmını dezorpsiyon ile uzaklaştırılması için yükseltilmiş sıcaklıklarda gerçekleştirilir [10,23]. Birincil kurutmanın temel amacı, çözücünün, matristen süblimasyon yoluyla uzaklaştırılması olmakla birlikte, ikincil kurutmanın temel amacı, ürünün nem içeriğini biyolojik aktivitelerin veya kimyasal reaksiyonların gerçekleşemeyeceği seviyelere düşürmektir. Liyofilizasyon işleminin bu aşaması aktif bileşenin kinetik saatini yavaşlatmak için bir araç olarak işlev görür. Kinetik saatin yavaşlaması, liyofilize edilmiş bir ürünün uzun süreli stabilitesini oluşturur. Böylece 4-8 $\mathrm{C}^{\circ}$ 'de kısa süre saklanabilen bir aşı, aynı ortam sıcaklığında aylarca veya y1llarca etkinliğini koruyarak muhafaza edilebilir [13]. Birincil kuruma tamamlandiktan sonra kek içeriğinde bulunan su molekülü miktarı, hedeflenen ürün stabilitesinin sağlanması için genellikle çok yüksek değerde olmaktadır [31]. Bu nedenle, nem içeriğinin kabul edilebilir değerlere düşürülmesi, ikincil kurutma işleminin başlıca işlevidir [13] Tüm donmuş su molekülleri süblimleştikten sonra ortamda yalnızca bağlı su kalır. Bağlı su katı matriksin içine hapsolmuştur ve uzaklaştırılması uzun sürebilir [20]. Bağl1 su üründen absorbe edildiğinden bu işlem "İzotermal Desorpsiyon" olarak adlandırılır. Düşük raf sıcaklığı ve orta seviyede vakumun kullanıldığ birincil kurutma işleminin aksine, ikincil kurutma raf sicaklığı yükseltilerek ve hazne basıncı minimuma indirilerek gerçekleştirilir. Fakat raf sıcaklığının yükseltilmesi adım adım yapılmalıdır, çünkü ikincil kuruma sırasında yüksek proses sıcaklığının kullanılması protein polimerizasyonu veya biyodegradasyona neden olabilir [10]. Ayrıca kollapsa uğramış ürün daha düşük bir yüzel alanına sahiptir ve buna bağlı olarak daha yavaş bir ikincil kurutma oluşur ki bu durum yüksek rezidüel su ve rekonstitusyon zamanında artış ile sonuçlanır [23].

İkincil kurutma esnasında numunenin çökmesi genellikle birincil kurutmada çökme olasılığından daha az olmasina rağmen, numunenin o fazdaki $\mathrm{Tg}$ noktasının üstündeki sıcaklığa maruz bırakılmasıyla kurutulan matriste kollapslar olabilir [15]. Bu yüzden, İkincil kurutma için raf sıcaklığı yavaşça artırılmalıdır, çünkü hızlı bir sıcaklık artışı, ikincil kurutma sırasında amorf yapıdaki üründeki yüksek rezidüel nem içeriğinden dolayı kollaps oluşmasına neden olabilir bu nedenle düşük Tg ikincil kurutma esnasında üründe kollaps oluşturma potansiyeline sahiptir [30]. Kristal ürünler, ikincil kurutma sırasında çökme potansiyeli göstermediğinden, bu ürünler için hızlı bir sıcaklık artışı önerilebilir [31]. Desorpsiyon hızı hazne basınç değeri $200 \mathrm{~m}$ Torr'dan (100-150 mTorr) düşük olana kadar bağ11 değildir, ancak desorpsiyon hızı ürün sıcaklığına (Tp) karşı çok hassastır [7]. Ürünler, suyun emilimine izin vermek için belirli bir süre daha yüksek sıcaklıkta tutulmalıdır. Daha uzun bir süre daha düşük sıcaklıkta bir döngü yerine, daha yüksek bir raf 
sıcaklığ 1 döngüsünü daha kısa bir zaman periyodu için çalıştırmak daha iyi bir seçenek olarak sunulmaktadır [31]. Belirli bir sıcaklıkta desorpsiyon hızı zamanla azaldığından, belli bir süre sonra nem içeriği seviyesinde az miktarda değişikliklere neden olur [21]. Amorf ürünlerin kurutulması, kristal halinde olan ürünlerden daha zor olduğundan dolayı bağlı suyun uzaklaştırılması için daha yüksek sıcaklıklara ve daha uzun zamanlara ihtiyaç duyulmaktadır [7].

İkincil kuruma koşulları ayrıca çözünen maddenin konsantrasyonuna bağlıdır. Çözünen maddenin konsantrasyonu yüksek olduğunda, kurutulmuş ürünün daha küçük spesifik alana sahip olması ve emilen suyun çıkarılması daha zor hale geldiğinden, ikincil kurutma daha uzun zamanda veya daha yüksek sıcaklıkta gerçekleşir [7,31]. Kurutmanın durumunu ortaya koymak için, birincil kurutmanın sonunda ve ikincil kurutmanın başında kurutucu hazneden numune alıc bir sistem ile örnekler al1narak rezidüel nem yüzdesi gravimetrik olarak veya Karl Fischer analizi yapılmaktadır [23].

Donmuş ürünün kurutulmasını birçok faktör etkilemektedir. Bu faktörler bağımsız olarak değerlendirilebileceği gibi birbirleri ile etkileşim içinde oldukları dinamik bir sistemi oluşturdukları unutulmamalıdır. Bu nedenle ancak faktörler arasında hassas bir denge kurulmuş kurutma reçeteleri ile uygun ürün elde edilebilir [3]. Başarılı liyofilizasyon prosesleri, üründeki kaybı azaltarak ve stabiliteyi arttırarak aşı üretim faaliyetlerinin verimliğini yükseltebilir. Liyofilizasyon prosesinde hedeflenen başarıya ulaşmak için, birbirleri ile etkileşim içinde olan basamaklar arasında geçişin uyum içinde olması gerekmektedir. Söz konusu gerekliliklerin yerine getirilmesi ancak prosesin anlaşılması ve doğru biçimde uygulanması ile mümkündür.

\section{Kaynakça}

1. Adams GDJ, Cook I, Ward KR, (2015). The Principles of Freeze-Drying. Wolkers WF, Oldenhof H. eds. Cryopreservation and Freeze-Drying Protocols. Springer, New York. p. 121-143.

2. Akyurt M, Zaki G, Habeebullah B, (2002). Freezing phenomena in ice-water systems. Energy Convers. Manag. 43, 1773-1789.

3. Anonim, (2017). A guide to freze drying for the laboratory. An industry service publication. Labconco, Erişim adresi: http://www.thermofishersci.in/lit/Labconco $\% 20-\% 20$
A\%20laboratory $\% 20$ guide $\% 20$ to $\% 20$ freeze $\% 20$ drying pdf. Erişim tarihi: 15.04.2018.

4. Carpenter JF, Pikal MJ,. Chang BS,. Randolph TW, (1997). Rational Desgin of Stable Lyophilized Protein formulatinos: Some Practical Advice. Pharm. Res. 14(8), 969-975.

5. Ciurzyńska A, Lenart A, (2011). Freeze-Drying - Application in Food Processing and Biotechnology - A Review. Pol. J. Food Nutr. Sci. 61(3), 165-171.

6. Cook I, (2018). Why, What and How? Understanding the freeze drying process Biopharma Technology Ltd. Erişim adresi: http://www.biopharma.co.uk/wp-content/ uploads/2010/07/Why_What_How.pdf. Erişim tarihi: 15.04.2018.

7. Deepak B, Iqbal Z, (2015). Lyophilization - Process and Opitimization for Pharmaceuticals. IJDRA, 3(1), 30-40.

8. Franks F, (1998). Freeze-drying of bioproducts: putting principles into practice, Eur. J. Pharm. Biopharm. 45, 221-229.

9. Franks F, (2007). Freeze-drying of pharmaceuticals and biopharmaceuticals, Cambridge: RSC Publishing, The Royal Society of Chemistry.

10. Gaidhani KA, Harwalkar M, Bhambere D, Nirgude PS, (2015). Lyophilization / Freeze Drying - A Review. WJPR 4(8), 516-543.

11. Halkman A, Doğan, HB, (2000). Gida Mikrobiyolojisi ve Uygulamaları. Genişletilmiş 2. Baskı, Ankara Üniversitesi Ziraat Fakültesi Gıda Mühendisliği Bölümü Yayını. Sim Matbaas1, Ankara.

12. Horn J, Friess W, (2018). Detection of Collapse and Crystallization of Saccharide, Protein, and Mannitol Formulations by Optical Fibers in Lyophilization. Front Chem. doi: 10.3389/fchem.2018.00004.

13. Jennigs TA, (2008). Lyophilization, introduction and basic principles. New York: Informa Healthcare.

14. Jiang S, Nail SL, (1998). Effect of process conditions on recovery of protein activity after freezing and freeze-drying. Eur J Pharm Biopharm. 45, 249-257.

15. John G. Day, Glyn N. Stacey eds., (2007) Cryopreservation and Freeze-Drying Protocols, Second Edition, New Jersey, Humana Press Inc.

16. Kasper JC, Friess W, (2011). The freezing step in lyophilization: Physico-chemical fundamentals, freezing methods and consequences on process performance and quality attributes of biopharmaceuticals. Eur J Pharm Biopharm. 78, 243-268.

17. Khairnar S, Kini R, Harwalkar M, Salunkhe K, Chaudhari $\mathrm{SR}$, (2013). A review on freeze drying process of pharmaceuticals, IJRPS. 4(1), $76-94$.

18. Matejschuk P, Stanley M, Jefferson P, (2010). Freeze-Drying of biological standards. Rey L, May JC. eds. Freze Drying/ Lyophilisation of Pharmaceutical and Biological Products. Third edition. Informa Healthcare, London. p.317-353.

19. Meister E, Gieseler H, (2008). A significant comparison between collapse and glass transition temperatures. European Pharmaceutical Review. 5. Erişim adresi: https:// www.europeanpharmaceuticalreview.com/article/1479/a- 
significant-comparison-between-collapse-and-glass-transition-temperatures/ . Erişim tarihi: 15.04.2018.

20. Morgan CA, Herman N, White PA, Vesey G, (2006). Preservation of micro-organisms by drying; A review. J Microbiol Methods. 66(2), 183-193.

21. Oetjen GW, (1999). Freeze drying. Germany: Wiley VCH.

22. Patapoff TW, Overcashier DE, (2002). The importance of freezing on lyophilization cycle development. Biopharm. 16-21.

23. Patel SM, Doen T, Pikal MJ, (2009). Determination of end point of primary drying in freeze-drying process control. AAPS Pharm Sci Tech, 11(1), DOI: 10.1208/s12249-0099362-7

24. Przic DS, Ruzic NLJ, Petrovic, SD, (2004). Lyophilizationthe process and industrial use. Chem. Ind. 58(12), 552-562.

25. Ratti C, (2012). Freeze - drying Process Design. Jasim A, Mohammad Shafiur R. eds. Handbook of Food Process Design, First Edition. Blackwell Publishing Ltd. New Jersey. p. 621-647.

26. Rey L, (2010). Glimpses into the realm of freeze-drying classical issues and new ventures. Rey L, May JC. eds. Freze Drying/Lyophilisation of Pharmaceutical and Biological Products. Third edition, Informa Healthcare, London. p.1-28.
27. Ross C, Gaster T, Ward K, (2008). Biopharma Technology Limited. The importance of critical temperatures in the freeze drying of pharmaceautical products. Erişim adresi:http://www.biopharma.co.uk/wp-content/uploads/2010/07/importance_critical_temps.pdf. Erişim tarihi: 15.04 .2018 .

28. Roy I, Gupta MN, (2004). Freeze-drying of proteins: some emerging concerns. Biotechnol Appl Biochem. 39(2), 16577.

29. Searless JA, Carpenter JF, Randolph TW, (2001). The ice nucleation temperature determines the primary drying rate of lyophilization for samples frozen on a temperature-controlled shelf. J. Pharm. Sci, 90(7), 860-871.

30. Searless JA, (2010). Freezing and anneling phenomena in lyophilization, Rey L, May JC. eds. Freze Drying/Lyophilisation of Pharmaceutical and Biological Products. Third edition, Informa Healthcare, London p.52-81.

31. Tang XC, Pikal MJ, (2004). Design of freeze-drying processes for pharmaceuticals: Practical advice. Pharm. Res. 21(2), 191-200.

32. Tsinontides SC, Rajniak P, Pham D, Hunke WA, Placek J, Reynolds SD, (2008). Freeze drying - principles and practice for successful scale-up to manufacturing. Int J Pharm. 280, 1-16. 